\title{
Sociodemographic and Clinical Features of Young Adult Males Using Synthetic Cannabinoid
}

\author{
Sentetik Kannabinoid Kullanan Genç Yetişkin Erkeklerde Sosyodemografik \\ ve Klinik Özellikler \\ Taner Öznur'1 , Havva Öznur², Abdullah Bolu³ ${ }^{3}$ Cemil Çelik¹, Kamil Nahit Özmenler ${ }^{4}$ \\ ${ }^{1}$ Assoc. Prof., ${ }^{3}$ Asist. Prof., 4 Prof. Department of Psychiatry, Gulhane Medical Faculty, University of Health Sciences, Ankara, Turkey \\ ${ }^{2}$ M.D., Department of Family Medicine, Gulhane Medical Faculty, University of Health Sciences, Ankara, Turkey
}

\section{SUMMARY}

Object: Synthetic Cannabinoid (SC) use is becoming more widespread throughout the world. Studies that revealed user profiles indicate that the drug is especially popular among young men. Knowledge on sociodemographic, clinical characteristics and motivation for SC users in our country is limited. On the other hand, in spite of the increase of information known about symptoms of acute intoxication of SC use, physical and psychiatric consequences and loss of function due to longterm use of SC is limited. In this study, we aimed to investigate socio-demographic and clinical characteristics associated with SC use and the negative consequences caused by the use of SC. Methods: 166 male patients who admitted to the psychiatric outpatient clinic due to SC use disorder between November 2014 to April 2015 were enrolled in the study. Demographic data of patients, substance use characteristics, familial substance use, reasons for substance use, medical history, the problems related to drug use was questioned. Results: The age of onset for SC use was found to be $17.25 \pm 2.30$. SC using duration was $3.79 \pm 2.15$ years. The most common agents accompanying SC use were smoking (95.8\%) and cannabis (88.6\%). It was determined that $62.7 \%$ developed suicidal ideas due to SC use. Among psychiatric side effects, most common were euphoria, hallucinations, skepticism and suicidal ideation. About $1 / 3$ of cases were found to live loss of business and legal issues depending on long-term SC use. $76.5 \%$ of the patients' consumed SC through inhalation and $22.9 \%$ orally. It was determined that oral users began SC use at an earlier age than users via inhalation. Discussion: Despite the physical, mental, occupational, social and legal problems caused by the use of SC, it has become an important public health problem, especially among young men. Effective intervention programs for the use of outbreaking SCs need to be developed.

Key Words: Synthetic cannabinoids, socio-demographic features, clinical features.

\section{ÖZET}

Amaç: Sentetik Kannabinoid (SK), kullanımı tüm dünyada yaygınlaşmaktadır. Kullanıcı profillerini ortaya koyan çalışmalar maddenin özellikle genç erkekler arasında yaygınlaştığını göstermektedir. Ülkemizdeki SK kullanıcılarının sosyo-demografik, klinik özelliklerini ve madde kullanımına yönelik motivasyonlarına yönelik bilgiler kısıtlıdır. Öte yandan SK kullanımına bağlı akut intoksikasyon belirtilerine dair bilgilerin artmasına karşın uzun süreli SK kullanımına bağlı bedensel ve psikiyatrik sonuçlar ile yol açtığı işlev kayıpları hakkında bilinenler yetersizdir. Bu çalışmada, SK kullanımıyla ilişkili sosyodemografik, klinik özellikler ile SK kullanımının yol açtığı olumsuz sonuçların araştııılması amaçlanmıştır. Yöntem: Çalışmaya Kasım 2014-Nisan 2015 tarihleri arasında SK kullanımı nedeniyle psikiyatri polikliniğine başvuran SK kullanım kozukluğu tanısı konulan 166 erkek hasta alındı. Hastaların sosyodemografik bilgileri, madde kullanım özellikleri, ailesel madde kullanımı, madde kullanma gerekçeleri, tıbbi özgeçmişi, madde kullanımına bağlı yaşanan sorunlar ve istismar öyküsü sorgulandı. Bulgular: SK kullanımına başlama yaşı 17.25 \pm 2.30 olarak bulundu. SK kullanım süresi $3.79 \pm 2.15$ yıldı. SK kullanımına en sık, sigara (\%95.8) ve kannabis (\%88.6) kullanımının eşlik ettiği bulundu. \%62.7'inde SK kullanımına bağlı intihar düşüncesi geliştiği belirlendi. Psikiyatrik yan etkiler içerisinde en sık öfori, hallüsinasyon, şüphecilik ve intihar düşüncesinin geliştiği saptandı. Uzun süreli SK kullanımına bağlı olarak olguların yaklaşık $1 / 3$ 'nün iş kaybı ve yasal sorun yaşadığı bulundu. Sonuç: SK kullanıcılarının sosyo-demografik özelliklerinin ve kullanma gerekçelerinin belirlenmesi, etkin müdahale programlarının geliştirilmesine katkıda bulunabilir. Ayrıca SK'lerin uzun süreli kullanımının yol açtığı olumsuzlukların ortaya konulmasının bu psikotrop ajanların popülerliğine katkıda bulunan doğal ve zararsız ürünler olduğu yönündeki genel kanının değişimine katkıda bulunabileceği değerlendirilmektedir.

Anahtar Sözcükler:Sentetik kannabinoidler, sosyodemografik özellikler, klinik özellikler.

(Turkish J Clinical Psychiatry 2018;21:15-23)

DOI: $10.5505 / k p d .2018 .07269$. 


\section{INTRODUCTION}

The health problems that arise due to the increasing use of Synthetic Cannabinoids (SC) has reached serious levels. Use of SC is reported to be popular especially among teens and young adults (1). SCs began to be marketed through supermarkets and internet since 2004 in Europe. Although it was forbidden to use SC in 2008 in the United States, illegal sales of these substances continues (2). Lifetime prevalence of SC use was found as 8.1-16.8\% at follow-up studies (3).

Increase in the cases of intoxication caused by SC use is striking. According to the US National Poison Data System records, the number of calls related to the use of the SC-induced side effects in 2015 showed a $229 \%$ increase compared to the previous year (4). Similarly, dramatic increase have been seen in intoxication cases due to use of SC in Japan in the last few years. As well as physical complications, behavioral pathologies and psychotic symptoms were also observed in these cases (5). In US National Poison Data System records of 2015, serious side effects has been found in $11.3 \%$ of the acute intoxication cases due to SC use (4).

Studies in Europe, US and Japan revealed that SC users vary among communities in terms of sociodemographic and clinical characteristics. While it was found that users in Europe and the US are mostly adolescent and young adult males $(1,6)$, SC using age in Japan was reported to be higher when compared to Western countries (5). It was found in studies that the use of other psychoactive substances with SC is common and the most commonly used psycho-active agents are alcohol and cannabis (7). SC are most commonly consumed in the form of smoking $(7,8)$. The most reasons of SC using are curiosity, relaxation request, not be detected in routine testing, to be easily accessible and more powerful effect than cannabis (9).

There are few studies on the use of SC in terms of psychiatry in Turkey $(10,11,12)$. In this study, we aimed to investigate socio-demographic and clinical characteristics associated with SC use and the negative consequences caused by the use of $\mathrm{SC}$ in an example of outpatient population.

\section{METHODS}

166 consecutive male patients referred to psychiatry outpatient clinic between November 2014 and April 2015, and diagnosed with "Cannabis Use Disorder" by a psychiatrist according to DSM-5 diagnostic criteria were enrolled in study. There is no female patient diagnosed with 'Cannabis Use Disorder' at study period. As well as the clinical assessment by a psychiatrist; sociodemographic information (age, education level, employment status) and legal (cigarettes, alcohol) and illegal substance abuse, physical and sexual abuse history, family history of substance abuse were questioned. Also, about the use of SC of patients; the age of onset, frequency of use, usage style, withdrawal symptoms, whether the thought of cessation is present, case of illegal actions for providing SC, medical help to stop, side-effects that was experienced, the problems caused by SC (job loss, school loss, accident, injury, health, legal) and reasons for use were investigated. Those considered to be under the influence of substance during interviews and those who refused to participate the study were excluded from the study. The trial was performed in accordance with the Declaration of Helsinki and subsequent revisions and approved by local ethics committee. Written informed consent was obtained before admitting subjects into the study.

\section{STATISTICAL ANALYSIS}

The data were analyzed with SPSS 15.0. Continuous variables are presented as mean \pm standard deviation, while categorical variables are expressed as frequency and percentages. Student $t$ test and chi-square test were used to compare respectively for continious and non-continious variables between oral and inhalation administration groups.

\section{RESULTS}

In the study, a total of 24896 patients admitted to the psychiatry clinic between November 2014 and April 2015, 166 (0.67\%) were diagnosed with SC use disorder. 


\section{Sociodemographic features}

All of the patients in the study sample were men, and the sociodemographic data is given in Table 1.

\section{Clinical features}

Clinical features associated with the use of SC is given in Table 2. Unemployment rate in taking SC more often than 5 times a week was 48/108 $(44.5 \%)$, while it was found as 19/58 (32.7\%)in users taking SC 4 times and fewer. Reasons for SC use is shown in Table 3 .

Side effects due to SC use are given in Table 4. Euphoria (74.1\%), hallucination (74.1\%), skepticism $(64.5 \%)$ and suicidal ideation $(62.7 \%)$ were the most common psychiatric side effects.

When side-effects were compared that arise due to the usage patterns; there were statistically significant differences in terms of appetite and difficulty in breathing and pupil changes (Table 5). Everyday $\mathrm{SC}$ users was found to begin at a lower age than less frequent SC users $\left(\mathrm{x}^{2}=33.431, \mathrm{p}<0.001\right)$. Problematic areas related to the use of SC are shown in Table 6.

\section{DISCUSSION}

\section{Prevalence-frequency}

In the study, the proportion of patients with diagnosis of SC use disorder was found to be $0.67 \%$ among patients who admitted to psychiatry outpatient clinic and it was determined that $54.8 \%$ of cases did not take medical advice previously. Only half of the SC users was seeking psychiatric treatment and referred to the psychiatric clinic. In our study, making no toxicological analysis may have led to the failure to diagnose some SC users. The frequency of SC use is estimated to be $2.8 \%$ in Germany and 4\% in France $(13,14)$. This rate in our study may not reflect real value. In a recent study, the frequency of SC use among patients who were hospitalized in a substance use disorder treatment center was reported to be $43 \%$ (12). Serving only to drug users of this study center thought to be led to relatively high proportion for use of SC.

\section{Age of onset-employment status}

In the study, age of onset of the SC users was 17.25 \pm 2.30 , duration of education was found to be 8.72 \pm 3.09 years. In other studies for SC users mean age of first use of Spice products was respectively 28.4, 21, $26(5,6,7)$. These findings shows that those begin at an earlier age to SC use in our country than Japan, US and Europe.

A recent study carried out in our country have reported that SC use begin during adolescence and at an earlier age than other substances (12). In our country, it was reported that easy access and cheapness contributed to the widespread use of SC, and according to official data the amount of captured SC had a 17-fold increase in three years (15). In accordance with the results of our study, it is considered that SD prevention programs should be conducted especially in adolescence.

In this study, unemployment rate among $\mathrm{SC}$ users was $40.4 \%$, this rate was found to be $32.7 \%$ among

Table 1: Socio-demographic characteristics of the patients with SC abuse disorder.

\begin{tabular}{lc}
\hline & Case (n=166) \\
\hline Age (years) & $21.04 \pm 1.04$ \\
mean \pm SD & $21(20-24)$ \\
median (min -max) & \\
\hline Education level (years) & $8.72 \pm 3.09$ \\
mean \pm SD & $8(0-16)$ \\
median (min -max) & $67(40.4)$ \\
\hline Working status & $99(59.6)$ \\
Not working $\mathrm{n}(\%)$ & $\mathrm{n}(\%)$ \\
\hline
\end{tabular}


Table 2: Clinical features associated with the use of SC.

\begin{tabular}{|c|c|}
\hline Clinical feature & Case $(n=166)$ \\
\hline \multicolumn{2}{|l|}{ The age of onset (years) } \\
\hline mean $\pm \mathrm{SD}$ & $17.25 \pm 2.30$ \\
\hline median (min -max) & $18(11-22)$ \\
\hline \multicolumn{2}{|l|}{ Duration of using (years) } \\
\hline mean $\pm \mathrm{SD}$ & $3.79 \pm 2.15$ \\
\hline median (min-max) & $3(0-9)$ \\
\hline Accompanying drug use * & n (\%) \\
\hline Cigarette & $159(95.8)$ \\
\hline Cannabis & $147(88.6)$ \\
\hline Alcohol & $88(53)$ \\
\hline Cocaine & $72(43.4)$ \\
\hline Heroin (nasal inhalation) & $63(38)$ \\
\hline Inhalant & $43(25.9)$ \\
\hline Ecstasy & $56(33.7)$ \\
\hline LSD & $16(9.6)$ \\
\hline Amphetamine & $21(12.7)$ \\
\hline None & $7(4.2)$ \\
\hline \multicolumn{2}{|l|}{ SC Using method } \\
\hline Inhalation (Cigarette, pipe, waterpipe, bong) & $127(76.5)$ \\
\hline Oral & $38(22.9)$ \\
\hline Injection & $1(0.6)$ \\
\hline \multicolumn{2}{|l|}{ Weekly Frequency of Use } \\
\hline Daily & $92(55.5)$ \\
\hline $5-6$ times & $16(9.6)$ \\
\hline 3-4 times & 19(11.4) \\
\hline 1-2 times & $39(23.5)$ \\
\hline \multicolumn{2}{|l|}{ Medical help for cessation } \\
\hline None & $91(54.8)$ \\
\hline One time & $55(33.1)$ \\
\hline Regular & $20(12.1)$ \\
\hline \multicolumn{2}{|l|}{ Withdrawal } \\
\hline Yes & $133(80.1)$ \\
\hline No & $33(19.9)$ \\
\hline \multicolumn{2}{|l|}{ Desire for cessation } \\
\hline Yes & 131(78.9) \\
\hline No & $35(21.1)$ \\
\hline \multicolumn{2}{|l|}{ Illegal action for SC supply } \\
\hline Yes & $48(28.9)$ \\
\hline No & $118(71.1)$ \\
\hline
\end{tabular}

*: Some participants choose multiple options. 
users who use 4 times or less a week while it was $44.5 \%$ in users who use SC more frequent than 4 at a week. Frequency of use of SC affects the unemployment level.

\section{Comorbid drug use}

In the study, it was found that the most common agents accompanying SC use were smoking, cannabis and alcohol. It was determined that $95.8 \%$ of the cases had concurrent smoking and 88.6\% consumed cannabis. Smoking and cannabis use were found to frequently accompany to SC use also in other studies $(3,6,9,16)$. Additionally, it was revealed that $53 \%$ of patients had comorbid alcohol use. Cigarettes, alcohol and, cannabis, are as cheap and easy to obtain as in SC, this may be the reason for comorbid use of them. As a result, use of multiple substances frequently accompany to the use of SC also in our patients as in other societies.

\section{Route of administration}

It has been found in the study that SC was most frequently consumed by inhalation, the oral administration was second. Similarly, it was stated that SC were most consumed by inhalation $(7,8,9)$. In our study, preferred method for consumption as steam was through smoking in most of the cases. Conveniently, Bonar et al. stated smoking as the most commonly used method, Barrat et al. reported the most commonly used method as waterpipe $(8,9)$. Unlike other studies $(7,8,9)$ consumption as

Table 3: Reasons for SC use

\begin{tabular}{lll}
\hline Reasons for SC use $(\mathrm{n}=166)$ & $\mathbf{n}$ & $\mathbf{\%}$ \\
\hline Friend group & 118 & 71.1 \\
\hline Relaxing effect & 110 & 66.3 \\
\hline Euphoric effect & 107 & 64.5 \\
\hline Dependency & 69 & 41.6 \\
\hline Cheapness & 64 & 38.6 \\
\hline Being easily accessible & 64 & 38.6 \\
\hline Aim of trying & 51 & 30.7 \\
\hline to strengthen the cognitive functions & 27 & 16.3 \\
\hline Analgesic effect & 26 & 15.7 \\
\hline not be detected by routine screening & 19 & 11.4 \\
\hline *: Some participants choose multiple options. &
\end{tabular}

Table 4: Side effects due to SC use.

\begin{tabular}{lll}
\hline Clinical side effects $(\mathrm{n}=166)$ & $\mathbf{n}$ & $\mathbf{\%}$ \\
\hline Slowing in movements & 121 & 72.9 \\
\hline Altered consciousness & 119 & 71.7 \\
\hline Speech difficulties & 118 & 71.1 \\
\hline Loss of balance & 113 & 68.1 \\
\hline Tremor & 107 & 64.5 \\
\hline Headache & 76 & 45.8 \\
\hline Involuntary movement & 74 & 44.6 \\
\hline Epileptic seizures & 19 & 11.4 \\
\hline Euphoria & 123 & 74.1 \\
\hline Hallucination & 123 & 74.1 \\
\hline Skepticism & 107 & 64.5 \\
\hline Suicidal ideation & 104 & 62.7 \\
\hline Memory loss & 92 & 55.4 \\
\hline Panic attack & 88 & 53 \\
\hline Depression & 82 & 49.4 \\
\hline Anxiety & 79 & 47.6 \\
\hline Palpitation & 120 & 72.3 \\
\hline Irregular Blood pressure & 57 & 34.3 \\
\hline Dry mouth & 144 & 86.7 \\
\hline Weakness & 136 & 81.9 \\
\hline Change in appetite & 131 & 78.9 \\
\hline Watery eyes & 108 & 65.1 \\
\hline Difficulty breathing (dyspnea) & 103 & 62 \\
\hline Nausea & 88 & 53 \\
\hline Fading skin & 63 & 38 \\
\hline High fever & 57 & 34.3 \\
\hline Pupillary changes & 54 & 32.5 \\
\hline Skin eruption & 39 & 23.5 \\
\hline : Some partipants & 07107 & \\
\hline
\end{tabular}

*: Some participants choose multiple options.

chewing in the mouth of SC was found high $(22.9 \%)$ in our study. There are a small number of case reports in the literature that psychotropic effects are available depending on the oral use of SC (17).

In our study, statistically significant differences was found in terms of side effects that occur depending on the consumption method of SC. Consumption by inhalation was found to produce more appetite changes $\left(\mathrm{x}^{2}=5,585, \mathrm{p}=0.018\right)$ and cause difficulty in breathing than oral way. On the other hand, orally consumption was found to lead more pupil changes than consumption by inhalation. No diffe-rence was determined in terms of frequency of use between inhalation and oral SC users $\left(\mathrm{x}^{2}=\right.$ 2.17 and $p=0.54$ ), but oral SC users started using $\mathrm{SC}$ at an earlier age than those using by inhalation $(\mathrm{t}=2.58, \mathrm{p}=0.01)$. 
Table 5: Comparison of side effect and clinical features of inhalation or oral administration of Synthetic cannabinoids.

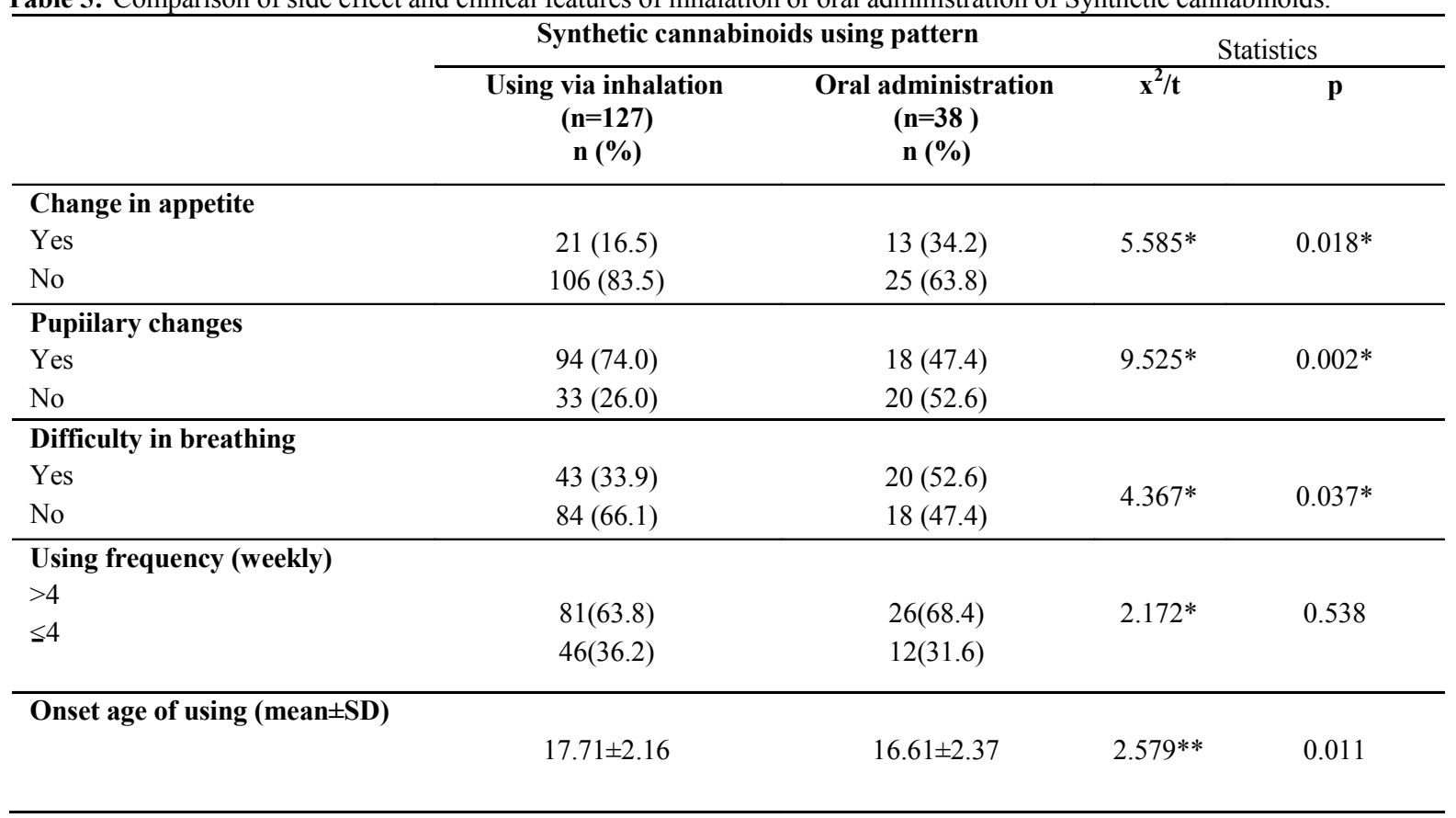

*: Chi-square value, $* *$ : Student $-\mathrm{t}$ test value.

\section{Frequency of use, indications and side effects}

It was found in the study that $55 \%$ of cases use SC every day, $76.5 \%$ more than two in a week. Everyday use of SC has been reported as $7 \%$ in the Barrett et al.' s study and $4.8 \%$ in Winsock et al.'s study $(6,9)$. Use of daily SC was more frequent than other community users. The age of onset of every day SC users was found to be lower than those who use less often SC $(\mathrm{t}=33.431, \mathrm{p}<0.001)$.

In the study, $80.1 \%$ of the cases was found to experience withdrawal symptoms, $78.9 \%$ wants cessation, $41.6 \%$ stated that they use SC due to dependence. Neurological, psychiatric and somatic side effects was determined due to SC use. The most common neurological side effects were slowing of movements, slurred speech, loss of consciousness, and change in balance. Tremor was determined in $64.5 \%$ of cases, involuntary movements occured at $44.6 \%$, epileptic seizures developed in $11.4 \%$ in our study. These neurological symptoms due to the use of SC are usually seen during intoxication, but in some cases it has been reported that they could be observed for a longer time (2).

The most common experienced psychiatric side effects were euphoria, hallucination, skepticism and suicidal ideation. The euphoria was the most common psychiatric side effect experienced in this study, and it was reported in the first place among the reasons for the use of SC. Therefore euphoria is considered to have a significant impact on the continuity of the SC use. Skepticism in relation to the SC use was detected as $64.5 \%$, hallucinations was $74.1 \%$. Acute psychotic symptoms have been reported to trigger in susceptible individuals or in patients who have a history of psychiatric illness with SC effect (18).

Suicidal ideation related to the use of SC was found to develop in $62.7 \%$ of patients in the study. SC use at young soldiers was reported to be high in studies (19) and the evidence is increasing that it may be associated with suicide attempts in conjunction with the other facilitator factors (20). There is a 
Table 6: The problematic areas related to the use of SC.

\begin{tabular}{lcc}
\hline The problematic areas related to the use of SC (n=166) & Number (n) & \% \\
\hline Job losses & 55 & 33.1 \\
\hline Legal issues & 51 & 30.7 \\
\hline Health problems & 46 & 27.7 \\
\hline Injury & 45 & 27.1 \\
\hline Dropped out of school & 42 & 25.3 \\
\hline Accident & 31 & 18.7 \\
\hline *: Some participants choose multiple options. & &
\end{tabular}

need for new studies examining the relationship between SC use and suicide.

About half of the cases was found to experience memory problems, depression, panic attacks and anxiety. Related with that, it was reported that SC use impair memory function in the acute phase (2), long-term heavy cannabis use caused a decrease in hippocampus volume (21). In our study, half of patients have experienced depression, who are largely multiple substance user and heavy drinkers. Similarly, Bonar et al. determined that patients with long-term $\mathrm{SC}$ use had higher frequency for the use of other substances and had more severe depression (8). Anxiety and panic attacks have been reported to occur frequently associated with the use of SC $(2,5,22)$.

\section{Reasons to use}

The most common reason in the study to use SC was found as friend group $(71.1 \%)$. Similarly, it has been shown in previous studies that $91 \%$ of the SC users had contact with the substance by a friend and $76 \%$ provided SC from a friend (16). In this study, the relaxing $(66.3 \%)$ and euphoric effects $(64.5 \%)$ were found to be other reasons for preference. $41.6 \%$ of the patients stated that they use SC because of being dependent. Only $16 \%$ of patients in the Bonar et al.' s study reported that they used $\mathrm{SC}$ for the same reason (8). These difference in our study is considered to be due to the high proportion of patients living withdrawal symptoms. $38.6 \%$ of the patients reported that they preferred SC because it is cheaper and easier to reach than other psychotropics. Despite being banned since 2011, it is understood that $\mathrm{SC}$ is still easy to obtain in our country. $11.4 \%$ of the cases prefer SC because of not to be detected in routine screening. This rate is similar to some studies (9), but lower than some
$(7,8)$. The lack of knowledge about the presence or absence of identifying SC in routine screening of $\mathrm{SC}$ users in our country can cause this condition.

\section{Negative consequences of SC use}

The patients most common experienced loss of business due to $\mathrm{SC}$ use. When taken together the high rate of dependence level of cases, and the physical and psychological side effects experienced, the reason for the loss of business at one out of every three user is better understood.

Also, $30.7 \%$ of cases faced with legal problems, the proportion of cases who made illegal actions for the supply of SC has been determined in $28.9 \%$. In other words, one out of every three users are faced with legal issues and made an illegal action for providing SC. In accordance, a recent study reported that SC users are faced with more legal problems compared to other drug users, and criminal records can be used as a marker for predicting the use of SC (12).

Despite the cases largely live side effects, rate of regular medical treatment is $12.1 \%$. It is considered that marketing SC as natural harmless products and low awareness about the negative impact on the health due to recent emergence at all over the world reduce the medical help rates.

In association, it has been reported that, despite the harmful consequences, the SC users show very little help-seeking behavior (9). \%27.7 of patients reported that they have health problems due to long term SC use in this study.

Depending on the use of SC, $27 \%$ of the cases was determined to have injuries and accidents. It has 
been reported in one study that, $10.8 \%$ of patients admitted to the emergency room after SC use had pathological behaviors as harm to around and selfharm, suicide and traffic accidents (5). Injuries and accidents are evaluated to occur due to neurological and psychiatric symptoms of intoxication.

$25.3 \%$ of SC users in the study were found to drop out of school. In association, the average training time of SC users have been reported to be shorter than other substance users (12). As a result, SC use which was initiated at an early age is considered to lead dropout and shorter training time.

\section{Limitations}

Cross-sectional design of the study, the absence of a control group, to obtain data from feedback of patients from the retrospective data constitute the methodological limitations of this study. Because of not making a toxicological examination, not determining chemical structure of substances which the patient declares that he uses is another limitation of the study. Being all of the patients male gender in the study makes it difficult to generalize the results. Controlled follow-up studies that contain toxicological and biochemical analyzes are needed for more objectively determining the negative consequences caused by SC.

\section{CONCLUSION}

In this study, the socio-demographic and clinical features of young men who applied to the psychiatry outpatient clinic for the use of SC were evaluated. Young age of SC in our country compared to other countries were found to be significantly lower and heavy smokers were found to be at higher levels. On the other hand, it has been found that the frequency of use may be related to the unemployment rate. It has been shown that SC usage way leads to different psychotropic effects, and chewers experience more visual problems than others. Although SC users have a high rate of suicide ideation, there is a need for new studies to investigate the causality between these two. The use of SC has been found to have a very low rate of seeking medical help before attendance, despite the fact that it is accompanied by educational and occupa- tional impairments and, legal problems. To determine the socio-demographic characteristics and reasons for the use of SC users will contribute to the development of effective intervention programs.

As a result, in addition to the acute side effects of SC, permanent psychiatric and physical side effects was determined due to the long-term use of SC which has become a common health problem for the whole world. SC use was found to have serious consequences affecting the level of functionality in the form of loss of business, school dropout, delinquency, and having accident.

Correspondence address: Assoc. Prof. Taner Oznur, Health Sciences University, Faculty of Gulhane Medicine, Department of Psychiatry, Ankara, Turkey drtaneroznur@gmail.com 


\section{KAYNAKLAR}

1. Brewer TL, Collins M. A review of clinical manifestations in adolescent and young adults after use of synthetic cannabinoids. Journal for Specialists in Pediatric Nursing 2014; 19 (2): 119126.

2. Spaderna M, Addy PH, D'Souza DC. Spicing things up: synthetic cannabinoids. Psychopharmacology 2013; 228 (4): 525540 .

3. Hu X, Primack BA, Barnett TE, Cook RL. College students and use of K2: An emerging drug of abuse in young persons. Substance abuse treatment, prevention, and policy 2011; 6: 16 .

4. Law R, Schier J, Martin C, Chang A, Wolkin A. Notes from the field: Increase in reported adverse health effects related to synthetic cannabinoid use-United States, January-May 2015. MMWR Morb Mortal Wkly Rep 2015; 64 (22): 618-619.

5. Kamijo Y, Takai M, Fujita Y, Hirose Y, Iwasaki Y, Ishihara S, Yokoyama T, Yagi K, Sakamoto T. A multicenter retrospective survey of poisoning after consumption of products containing synthetic chemicals in Japan. Internal Medicine 2014; 53 (21):2439-2445.

6. Winstock AR, Barratt MJ. Synthetic cannabis: A comparison of patterns of use and effect profile with natural cannabis in a large global sample. Drug and alcohol dependence 2013; 131 (12):106-111.

7. Vandrey R, Dunn KE, Fry JA, Girling ER. A survey study to characterize use of spice products (synthetic cannabinoids). Drug and alcohol dependence 2012; 120 (1-3): 238-241.

8. Bonar EE, Ashrafioun L, Ilgen MA. Synthetic cannabinoid use among patients in residential substance use disorder treatment: Prevalence, motives, and correlates. Drug and alcohol dependence 2014; 143: 268-271.

9. Barratt MJ, Cakic V, Lenton S. Patterns of synthetic cannabinoid use in Australia. Drug and alcohol review 2013; 32(2): 141 146.

10. Bozkurt M, Umut G, Evren C, Karabulut V. Sentetik kannabinoid kullanımı nedeniyle polikliniğe başvuran hastaların klinik özellikleri ve laboratuvar sonuçları. Düşünen Adam Psikiyatri ve Nörolojik Bilimler Dergisi 2014;27:328-34.

11. Dogan H, Özücelik DN, Aciksari K, Avci A, Yazicioğlu M, Celikmen MF, Karşidağ Ç, Erkiran M, Aksoy UM. New synthetic cannabinoid intoxications in emergency department (It's grass, It's no sin). Anadolu Psikiyatri Derg 2016; 17(1): 18-25.

12. Nurmedov S, Yilmaz O, Darcin AE, Noyan OC, Dilbaz N. Frequency of Synthetic Cannabinoid Use and Its Relationship with Socio-Demographic Characteristics and Treatment Outcomes in Alcohol-and Substance-Dependent Inpatients: A retrospective study. Klinik Psikofarmakoloji Bulteni 2015; 25 (4): 321-434.

13. Debruyne D, Le Boisselier R. Emerging drugs of abuse: Current perspectives on synthetic cannabinoids. Substance abuse and rehabilitation 2015; 6: 113 .

14. Jaenicke NJ, Pogoda W, Paulke A, Wunder C, Toennes SW. Retrospective analysis of synthetic cannabinoids in serum samples-epidemiology and consumption patterns. Forensic science international 2014;242: 81-87.
15. EMCDDA. European Drug Report 2014: Trends and Developments. 2014.

16. Gunderson EW, Haughey HM, Ait-Daoud N, Joshi AS, Hart CL. A survey of synthetic cannabinoid consumption by current cannabis users. Substance abuse 2014; 35(2): 184-189.

17. Obafemi AI, Kleinschmidt K, Goto C, Fout D. Cluster of acute toxicity from ingestion of synthetic cannabinoid-laced brownies. Journal of medical toxicology : Official journal of the American College of Medical Toxicology 2015; 11(4): 426-429.

18. Papanti D, Schifano F, Botteon G, Bertossi F, Mannix J, Vidoni D, Impagnatiello M, Pascolo-Fabrici E, Bonavigo T. "Spiceophrenia": A systematic overview of "spice"-related psychopathological issues and a case report. Human psychopharmacology 2013; 28 (4): 379-389.

19. Berry-Caban CS, Kleinschmidt PE, Rao DS, Jenkins J. Synthetic cannabinoid and cathinone use among US soldiers. US Army Medical Department journal 2012: 19-24.

20. Shlosberg D, Zalsman G, Shoval G. Emerging issues in the relationship between adolescent substance use and suicidal behavior. The Israel journal of psychiatry and related sciences 2014; 51 (4): 262-267.

21. Seely KA, Lapoint J, Moran JH, Fattore L. Spice drugs are more than harmless herbal blends: A review of the pharmacology and toxicology of synthetic cannabinoids. Progress in Neuropsychopharmacology \& Biological Psychiatry 2012; 39(2): 234243.

22. Muller HH, Kornhuber J, Sperling W. The behavioral profile of spice and synthetic cannabinoids in humans. Brain Res Bull. $2016 ; 126(1): 3-7$. 